\title{
Environmental DNA: A New Method to Explore the Ichthyological Biodiversity of the Amazon Basin
}

\author{
Santos CHA* \\ Laboratory of Ecophysiology and Molecular Evolution (LEEM), Brazilian National \\ Research Institute of the Amazon, Brazil
}

*Corresponding author: Carlos HA Santos, Laboratory of Ecophysiology and Molecular Evolution, Brazilian National Research Institute of the Amazon, 69067375, Manaus, AM, Brazil, Tel: +55 92 984210000; Email: carloshenriqueufc@gmail.com

\section{Opinion}

Volume 3 Issue 2

Received Date: June 24, 2019

Published Date: July 22, 2019

DOI: $10.23880 /$ jenr-16000164

\section{Abstract}

The Amazon basin is an important region and intriguing in terms of diversity of freshwater fish. Traditional methods has been essential in knowledge the fishes species diversity in the region, but new methods are essential for the monitoring of this biodiversity. The environmental DNA method is a novel, sensitive, efficient, effective and noinvasive method in biological research. However, the sensitivity of the eDNA has not yet been fully evaluated, and the probability of detecting species at the site of study has been shown to be dependent of the environmental factors, sample collection methods, laboratory methods, and data analyzes. Thus, this opinion seek give the light in the research that were development in the region with applied this innovative method.

\section{Opinion}

The Amazon region was formed during the Pangea (with Africa in the central part), and throughout the geological ages and the climatic periods the region acquired its present format. Today, we find in this region the largest rainforest humid and the largest freshwater river of the world [1,2]. The biodiversity of the Amazon Basin is recognized worldwide by the their large diversity of species, but also because it is a region with great potential for discovery of new species. However, the anthropic actions and the climate changes have threatened aquatic biodiversity of the region.

In the Brazilian territory, the Amazon hydrographic basin has an area of drainage with 5.8 millions $\mathrm{km}^{2}$ [3], and their water are rich in diversity of fish species, with an estimated 2,416 species cataloged (2,072 would be species endemic) [4], and a great variety of species that have not yet been described. Faced with this, the main groups representing this ichthyological biodiversity are: Characiformes, Siluriformes, Gymnotiformes, Cyprinodontiformes, and Cichlids [4].

The distribution of the species of fishes in the Brazilian Amazon rivers follow the ecological traits in associated with the preference of the environmental conditions requerid to the species. Thus, the traditional methods have contributed to the knowledge of the local ichthyofauna in some Amazonian regions, but the traditional methods are selective in relation to the species, and therefore do not cover the real diversity [5]. Thereover, the tropical freshwater ecosystems (Figure 1), where local fishes assemblages contain dozens of species, 
his observation ends up being limited by water turbidity, depth and current velocity [6]. In this context, new methods are necessary to monitor the known biodiversity, as well as discover new species.

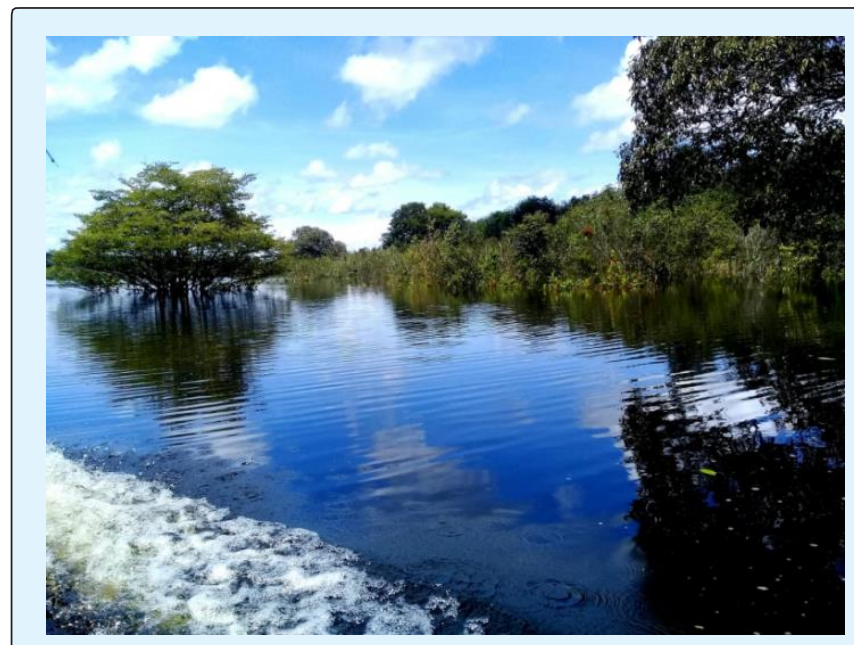

Figure 1: Field activity in the Rio Negro tributary to collect water samples for a environmental DNA study in the Brazilian Amazon.

The environmental DNA (eDNA) is a novel, sensitive, efficient, effective and noninvasive method in biological research [7], and is composed by the DNA capture in environmental samples, genetics analysis and analysis of results for metabarcoding data [8,9]. Thereover, particular attributes of eDNA analyzes have made this technique an important tool to elucidate the mechanisms related to evolutionary and ecological processes [10]. Thus, the application of eDNA is considered relatively recent in studies of monitoring and distribution of native species $[11,12]$. Studies have shown the high sensitivity of the eDNA technique in the detection of species in stationary waters is becoming increasingly clear, however, studies in running water are still necessary due to the controversial results obtained $[13,14]$.

Faced with this, the sensitivity of the eDNA method has not yet been fully evaluated, and the probability of detecting the target DNA at the site of study has been shown to be dependent on the concentration and dispersion methods of target DNA molecules [15], persistence of eDNA in the wild [16], preservation of the filters until the time of analysis [17], and the existence of several methods of extracting using commercial kits [18]. In this context, the need for the standardization of eDNA methods for new areas is evident, and given the peculiar characteristics of the Amazonian waters (black, clear, and white waters), it is of great importance that we establish a protocol to explore the eDNA technique in the types of waters found here.

\section{Final Remarkes}

In general, for an accurate application of eDNA in Amazonian aquatic environments, it is necessary to fill in some gaps about the method that need to be better studied before being applied routinely in the region. One of the larger challenges will be to expand the genetic database with informations of genomes mitochondriais or the complete sequencing of mitochondrial target-genes (12S, 16S, and Cytb) in the fishes species of the Amazon basin. However, the traditional methods and the ichthyological collections of the Amazonian region will be essential to achieve this goal. Another point will be to establish a protocol for the collection of water samples in the field, as well as a standardization of the laboratory methods (e.g., conservation of the collected material, types of filters suitable for filtering water samples, methods of DNA extraction, primers desing for specificspecies or universal, PCR assays, and eDNA metabarcoding protocols). Thereover, there is a need for people specializing in bioinformatics as well as the training of new people in the area for metabarcoding and next generation sequencing data analysis.

\section{Acknowledgments}

We acknowledge the Conselho Nacional de Desenvolvimento Científico e Tecnológico (CNPq) by the PCI/INPA fellowship (CNPq \#301402/2019-1) granted to CHAS to conduct research activities in the Instituto Nacional de Pesquisas da Amazônia (INPA)

\section{References}

1. Salati E (1985) The climatology and hydrology of Amazonia. In: Key environments Amazonia. Prance GT \& Lovejoy TE (Eds.), Pergamon Press, Oxford, pp: 18-48.

2. Porto C (2001) Macrocenários da Amazônia. Rev Parc Estrat 4(12): 187-213.

3. Ardura A, Linde AR, Moreira JC, Garcia-Vazquez E (2010) DNA barcoding for conservation and management of Amazonian commercial fish. Biol Conserv 143(6): 1438-1443. 
4. Lévêque C, Oberdorff T, Paugy D, Stiassny MJL, Tedesco PA (2008) Global diversity of fish (Pisces) in freshwater. Hidrobiologia 595: 545-567.

5. Gunzburger MS (2007) Evaluation of seven aquatic sampling methods for amphibians and other aquatic fauna. Appl Herpetol 4(1): 47-63.

6. Cilleros K, Valentini A, Allard L, Dejean T, Etienne R, et al. (2019) Unlocking biodiversity and conservation studies in high-diversity environments using environmental DNA (eDNA): A test with Guianese freshwater fishes. Mol Ecol Res 19(1): 27-46.

7. Rees HC, Maddison BC, Middleditch DJ, Patmore JRM, Gough KC (2014) The detection of aquatic animal species using environmental DNA - a review of eDNA as a survey tool in ecology. J Appl Ecol 51(5): 14501459.

8. Miya M, Fukunaga T, Sado T, Poulsen JY, Sato K, et al. (2015) MiFish, a set of universal PCR primers for metabarcoding environmental DNA from fishes: detection of more than 230 subtropical marine species. Royal Soc Open Sci 2(7): 150088.

9. Ma HJ, Stewart K, Ma LM, Ren WW, Zhao JF (2016) Environmental DNA and its application in protecting aquatic ecosystems. Chin J Ecol 35(2): 516-523.

10. Bohmann K, Evans A, Gilbert MTP, Carvalho GR, Creer S, et al. (2014) Environmental DNA for wildlife biology and biodiversity monitoring. Trends Ecol Evol 29(6): 358-367.

11. Pilliod DS, Goldberg CS, Arkle RS, Waits LP (2013) Estimating occupancy and abundance of stream amphibians using environmental DNA from filtered water samples. Can J Fish Aquat Sci 70(8): 11231130.
12. Souza LS, Godwin JC, Renshaw MA, Larson E (2016) Environmental DNA (eDNA) detection probability is influenced by seasonal activity of organisms. PLoS ONE 11(10): e0165273.

13. Mahon AR, Jerde CL, Galaska M, Bergner JL, Chadderton WL, et al. (2013) Validation of eDNA surveillance sensitivity for detection of asian carps in controlled and field experiments. PLoS ONE 8(3): e58316.

14. Jane SF, Wilcox TM, McKelvey KS, Young MK, Schwartz MK, et al. (2015) Distance, flow and PCR inhibition: eDNA dynamics in two headwater streams. Mol Ecol Res 15(1): 216-227.

15. Lacoursière-Roussel $A$, Côte $G$, Leclerc V, Bernatchez $L$ (2016) Quantifying relative fish abundance with eDNA: a promising tool for fisheries management. J Appl Ecol 53(4): 1148-1157.

16. Bista I, Carvalho GR, Walsh K, Seymour M, Hajibabaei $M$, et al. (2017) Annual time-series analysis of aqueous eDNA reveals ecologically relevant dynamics of lake ecosystem biodiversity. Nat Commun 8: 14087.

17. Renshaw MA, Olds BP, Jerde CL, McVeigh MM, Lodge DM (2015) The room temperature preservation of filtered environmental DNA samples and assimilation into a phenol-chloroform-isoamyl alcohol DNA extraction. Mol Ecol Res 15(1): 168-176.

18. Eichmiller JJ, Miller LM, Sorensen PW (2016) Optimizing techniques to capture and extract environmental DNA for detection and quantification of fish. Mol Ecol Res 16(1): 56-68. 